\title{
Soil carbon development in rejuvenated Indian coal mine spoil
}

\author{
Nimisha Tripathi ${ }^{\mathrm{a}, *}$, Raj S. Singh ${ }^{\mathrm{a}}$, Colin D. Hills ${ }^{\mathrm{b}}$ \\ a Central Institute of Mining and Fuel Research, Barwa Road, Dhanbad 826015, Jharkhand, India \\ b University of Greenwich, Chatham Maritime, ME4 4TB, UK
}

\section{A R T I C L E I N F O}

\section{Article history:}

Received 6 August 2015

Received in revised form 31 October 2015

Accepted 26 January 2016

Available online 27 February 2016

\section{Keywords:}

Mine spoil

Disposal

Land degradation

Re-vegetation

Age gradient

Root proliferation

Carbon development and accretion

Microbial biomass $\mathrm{C}$

Carbon budget

\begin{abstract}
A B S T R A C T
The impact of mine spoil on the landscape is significant, as excavated rock-debris is commonly disposed in heaps that blanket the original land surface. Spoil heaps destroy the original soil habitat releasing soilbound carbon, which is difficult to re-estate when mining operations cease and restoration begins. The present work follows the development of vegetative cover on a coalmine spoil tip in India over a period of 19 years following restoration. The potential of re-vegetated the mine spoil to imbibe carbon is examined through the development of above- and below-ground biomass development. It was observed that the soil organic carbon and microbial biomass carbon (MBC) significantly increased with re-vegetation age, with above ground biomass increasing by 23 times, and belowground biomass increased by 26 times during the period of study. Soil organic carbon and MBC increased by $4 \times$ and $6.6 \times$ times, respectively. The average calculated annual carbon budget was $8.40 \mathrm{~T} /$ ha/year, of which $2.14 \mathrm{~T} /$ ha was allocated to above ground biomass, $0.31 \mathrm{~T} /$ ha to belowground biomass, $2.88 \mathrm{~T} /$ ha to litter mass and $1.35 \mathrm{~T} /$ ha was sequestered into the soil. This work has shown that the development of biomass following the restoration of mine spoil was significant and that considerable quantities of carbon were stored in above and below ground plant matter, and in the soil itself. It is concluded that appropriate restoration strategies can be used to rapidly establish a viable, healthy and sustainable ecosystem that imbibes carbon into former mine-impacted land.
\end{abstract}

(C) 2016 Elsevier B.V. All rights reserved.

\section{Introduction}

Effective global carbon management strategies are required to mitigate the effects of the emission of carbon to the atmosphere $(405 \pm 30 \mathrm{Pg}$ carbon (C) over the past 200 years), and which arise from the burning of fossil fuels (75\%) and changes in land use (25\%) (IPCC, 2001). During the past 2 centuries these emissions have resulted in atmospheric $\mathrm{CO}_{2}$ concentrations rising from 280 to $400 \mathrm{ppm}$. An increase in global temperatures of $1.8-3.6 \%$ is predicted over the 21st Century (Macdonald et al., 2011), despite 60\% of anthropogenic emissions being removed from the atmosphere by ocean and terrestrial ecosystems (Canadell et al., 2007).

India is a major coal producer, with total coal production (from Coal India Limited) being 431 MT for the year 2010-2011. The amount of spoil generated by coal mining is significant, being typically $>2$ to 3 times that of the coal produced itself. Opencast coal mining operations produced 252 MT of spoil alone during that year (Singh, 2011). Mining spoil is typically dumped in heaps, which significantly degrade land quality and

\footnotetext{
* Corresponding author.

E-mail addresses: nymphaea7@gmail.com, rajcimfr@gmail.com (N. Tripathi).
}

disrupts/destroys existing ecosystems. Mining operations result in drastic landscape perturbations that cause major ecosystem damage, and irreparable impacts to former soil quality/nutrient cycling capability (Anderson et al., 2004; Shrestha and Lal, 2006).

The natural recovery of these disturbed habitats (i.e. colonization of the mine spoil) by plant and animal species extends over long timescales (of decades/centuries), can be shortened if the restoration of soil fertility and biological diversity can be managed. However, reclamation can return mined land to a useful (but not necessarily its original) state (Barnhisel and Hower, 1997; Bradshaw, 1997). As reclaimed mine soils are man-made or anthropic soils (Lal, 2004), the introduction of a sustainable vegetative cover is the key to the reconstruction of an ecosystem, as the development of soil 'quality' depends on an improvement of a soils physical, chemical and biological characteristics (Bradshaw, 1997).

Carbon dioxide is removed from the atmosphere by aboveground plant biomass, belowground root biomass and soil organisms, and in stable forms of soil organic (SOC) and inorganic (SIC) carbon, resulting in organic matter comprising $1-8 \%(w / w)$ of most soils. Because of this, the soils of the world store about 1600 Pg of carbon (Dakora and Phillips, 2000). The FAO (2001), estimates that $125 \mathrm{GT}$ of carbon are exchanged annually between vegetation, 


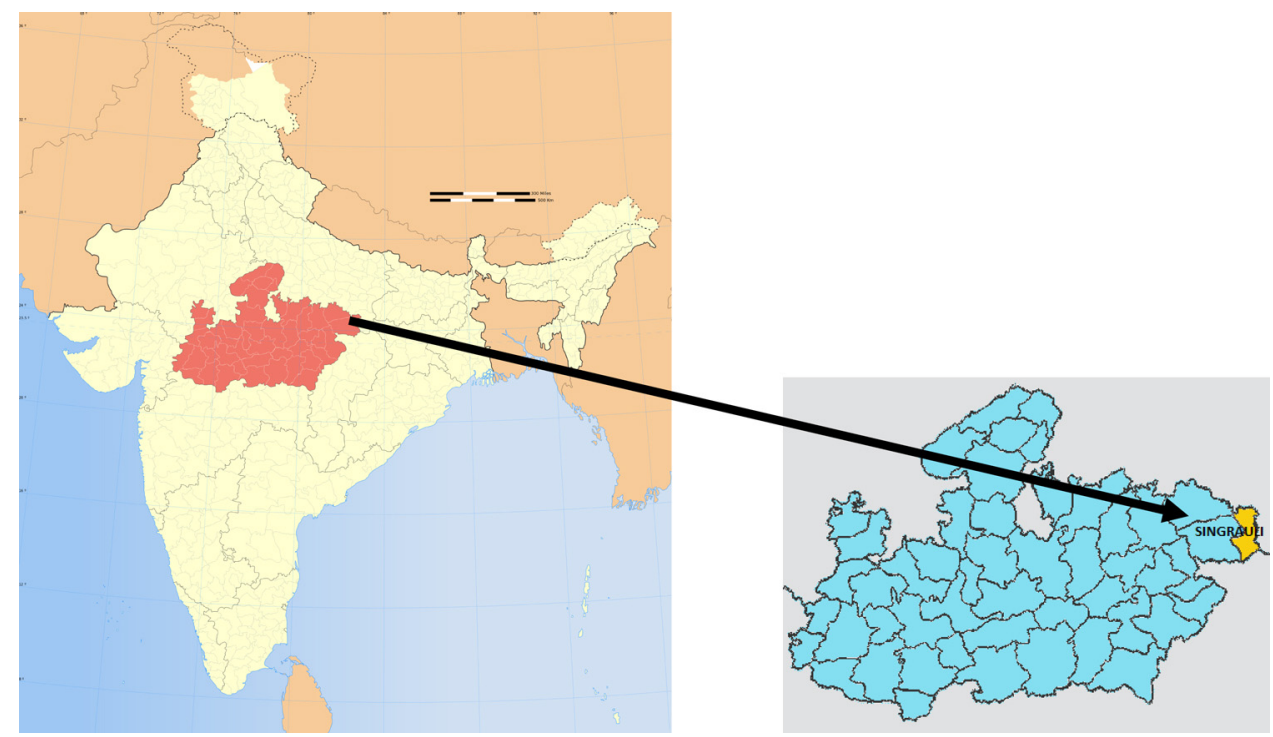

Fig. 1. Location map of study site.

soils and the atmosphere, with terrestrial sequestration accounting for two-fifths of the total exchange.

Therefore, if the re-vegetation of mine-spoil can be managed in shorter (than natural) timescales, increased biomass volumes will enhance the storage of carbon.

The focus of the present work is a long-term study of revegetated mine spoil which extended over 19 years following restoration by planting. The monitoring of key soil characteristics and biomass during this time provides important data that demonstrates the wider value of managed restoration of mine spoil through the increase in the amount of carbon stored in plant and mineral-carbon complexes.

\section{Study sites}

The present study was performed (during 2009-2011) on revegetated mine spoil, between $2,4,10,14,16$ and 19 years of age at Northern Coalfields Limited (NCL), Singrauli, India. The project site was located in Moher basin of Singrauli (between latitudes $24^{\circ} 08^{\prime} 45^{\prime \prime}$ to $24^{\circ} 11^{\prime} 25^{\prime \prime}$; longitudes $82^{\circ} 38^{\prime} 21^{\prime \prime}$ to $82^{\circ} 40^{\prime} 45^{\prime \prime}$ ) on the eastern border of Madhya Pradesh and Uttar Pradesh (Fig. 1). The area is undulating landscape with an elevation of $375 \mathrm{~m}$ to $500 \mathrm{~m}$ above MSL.

The area has an annual temperature ranging from 6.4 to $28^{\circ} \mathrm{C}$ and an annual rainfall average of $1069 \mathrm{~mm}$, of which about $90 \%$ occurs during the late June to September monsoon. The predominant geology is alternating sandstone and shale, with white and grey clays with ferruginous bands, carbonaceous shale and coal seams, providing for one of India's largest coalmines, in terms of total excavations (Singh, 2010).

The NCL excavated about $770 \mathrm{MT}$ of coal using shovel and dumper and about 22 MT of overburden between 1964 and 1965 with an average stripping ratio of $2.89 \mathrm{~m}^{3} / \mathrm{T}$. During 2005-2006 coal production increased to $133.86 \mathrm{MT}$, and to $>250 \mathrm{MT}$ by 2011-2012, with an average stripping ratio of $3.64 \mathrm{~m}^{3} / \mathrm{T}$.

Before mining the study site was gently to moderately sloping land, but the establishment of spoil heaps significantly changed relief by $20-30 \mathrm{~m}$. The dumps were 5 years of age in 1997 when their sides (with slopes of $<35^{\circ}$ ) were planted with: grass species (Stylohemata spp., Dinanath grass, Sawai grass) and tree species (Eucalyptus, Dalbergia sissoo, Pongamia pinnata, Prosopis juliflora, Silver oak, Terminalia chebula, Terminalia bellerica, Schizygium jambolana, Azadirachta indica, Emblica officinalis, Cassia samea, Leucena leucocephala, Acacia catechu, Shorea robusta, Bamboo, Pithecolobium dulce, Madhuca indica, Ficus religiosa, Ficus bengalensis, Bauhinia variegata, Delonix regia, Cassia fistula, Gmelina arborea, Peltopherum enormii).

\section{Materials and methods}

\subsection{Physical and chemical characteristics}

Mine spoil samples from the re-vegetated tips were collected (using a randomized block design) at different times and were characterized for, for example, $\mathrm{pH}$, Moisture, bulk density, water holding capacity, total nitrogen, total phosphorus and organic carbon.

Five soil samples were collected at each of the three replicate plots at three depths (upper $0-10,10-20$ and $20-30 \mathrm{~cm}$ ). Large pieces of plant material were removed by hand and the samples were composited to get one sample per plot. Each sample was sub-divided into two, with one (in its field-moist condition) used for determining moisture, available $\mathrm{N}$, available $\mathrm{P}$, and microbial biomass $\mathrm{C}$, and the other (air-dried) used for physical/chemical analysis.

Soil $\mathrm{pH}$ (soil: water ratio $=1: 2$ ) was estimated by ORION ion analyzer. Bulk density and water holding capacity were determined following Piper (1994). Organic C of soil was determined following Walkley Black's method and total $\mathrm{N}$ by modified Kjeldahl method (Jackson, 1958). Soil organic matter (SOM) was calculated by multiplying the percent organic $C$ by a factor of 1.72 following the standard practice that organic matter is composed of $58 \%$ carbon (Brady, 1985). For the determination of total P, the perchloric acid digestion method was followed (Mehta et al., 1954).

\subsection{Microbial biomass $C$}

Microbial biomass $C$ in soil sample was determined using the $\mathrm{CHCl}_{3}$ fumigation-incubation method of Jenkinson and Powlson (1976), except that liquid $\mathrm{CHCl}_{3}$ was used instead of vapour and $\mathrm{CO}_{2}-\mathrm{C}$ evolved from fumigated soil during 10-20 days was taken as control (Srivastava and Singh, 1988). Microbial C was calculated as: Microbial $\mathrm{C}=\mathrm{Fc} / 0.45$. 
Table 1

Key characteristics of re-vegetated mine spoil soils.

\begin{tabular}{|c|c|c|c|c|c|c|}
\hline \multirow{2}{*}{$\begin{array}{l}\text { Sites } \\
\text { Parameters }\end{array}$} & \multicolumn{6}{|c|}{ Age of re-vegetated mine spoils (years) } \\
\hline & 02 & 04 & 10 & 14 & 16 & 19 \\
\hline $\mathrm{pH}$ & 6.90 & 6.80 & 6 & 6.10 & 6.20 & 6.00 \\
\hline Sand (\%) & 80 & 78.0 & 75.0 & 74.5 & 77.0 & 75.0 \\
\hline Silt (\%) & 10.8 & 12.8 & 15.6 & 15.9 & 13.4 & 15.0 \\
\hline Clay $(\%)$ & 9.2 & 9.2 & 9.4 & 9.6 & 9.6 & 10.0 \\
\hline $\mathrm{BD}\left(\mathrm{g} / \mathrm{cm}^{3}\right)$ & 1.60 & 1.65 & 1.58 & 1.52 & 1.52 & 1.48 \\
\hline WHC (\%) & 18 & 0.77 & 0.95 & 1.07 & 25.4 & 26.5 \\
\hline SOC (kg/ha) & 3200 & 19.5 & 20.5 & 22.6 & 11,400 & 12,728 \\
\hline $\mathrm{TN}(\mathrm{kg} / \mathrm{ha})$ & 160 & 0.45 & 0.55 & 0.62 & 501.6 & 503.2 \\
\hline $\mathrm{TP}(\mathrm{kg} / \mathrm{ha})$ & 128 & 247.5 & 379.2 & 425.6 & 167.2 & 207.2 \\
\hline $\mathrm{MBC}(\mathrm{kg} / \mathrm{ha})$ & 156.8 & 189.75 & 860.32 & 939.8 & 943.58 & 1039.68 \\
\hline
\end{tabular}

\subsection{Plant biomass}

Above ground plant biomass was measured by harvesting five plants of each species at ground level and an empirical equation was developed with reference to diameter and height. The litter masses in re-vegetated mine spoils of both the study sites were measured in randomly placed five $1 \mathrm{~m} \times 1 \mathrm{~m}$ quadrates per sites. For belowground biomass (live + dead roots) five replicate monoliths of $25 \mathrm{~cm} \times 25 \mathrm{~cm} \times 10 \mathrm{~cm}$ followed by $>10-20 \mathrm{~cm},>20-30 \mathrm{~cm}$ depths size were sampled. The monoliths from all three depths were washed with a fine jet of water using a $0.5 \mathrm{~mm}$ mesh screen. Both above- and below-ground samples were oven dried at $80^{\circ} \mathrm{C}$ till the constant weight.

Quantification of aboveground biomass was done in May (at the time when the litter layer on the ground was maximum). The canopy biomass and belowground biomass of re-vegetated mine spoils of different age were measured in the months of September (at the time of peak biomass) (Srivastava and Singh, 1991).

\subsection{Carbon sequestration and budget}

Carbon sequestration in re-vegetated mine spoils was quantified by following the methods described by Atjay et al. (1979), Brown and Lugo (1982), Cannell and Milne (1995), Dixon et al. (1994) and Shrestha and Lal (2006). CO $\mathrm{CO}_{2}$ equivalent was calculated assuming $1 \mathrm{~T}$ carbon $=3.66 \mathrm{TCO}_{2}$ equivalent (https://conference ifas.ufl.edu/citrus10/./1610\%20Spreen.pdf).

\subsection{Statistical analysis}

The statistical analyses (analysis of variance, least significant difference) of the mean values of the re-vegetated mine spoil data were done following Snedecor and Cochran (1989) and SPSS (1997).

\section{Results and discussion}

\subsection{Physico-chemical characterization}

The key characteristics of mine spoil soils are given from Tables 1 and 2.

The spoils have shown a change in soil $\mathrm{pH}$ from 2 to 19 years, with a reduced acidity of $13 \%$. The texture of the soils also changed between 2 and 19 years (after re-planting), with a decline in sand content of $6 \%$ and an increase in silt and clay contents of 39 and $9 \%$, respectively. Soil bulk density was declined by nearly $8 \%$, while the water holding capacity increased $47 \%$ following re-vegetation. There was an increase in total nitrogen and total phosphorus contents by $214 \%$ (3.14 times) and $62 \%$, respectively. An increase in $\mathrm{BD}$ and a decrease in SOC, SOM, TN, TP and MBC across increasing depth of soil were observed.

Table 2

Key characteristics of re-vegetated mine spoil soils.

\begin{tabular}{|c|c|c|c|c|c|c|c|}
\hline \multirow{2}{*}{$\begin{array}{l}\text { Sites } \\
\text { Parameters }\end{array}$} & & \multicolumn{6}{|c|}{ Age of re-vegetated mine spoils (years) } \\
\hline & & 02 & 04 & 10 & 14 & 16 & 19 \\
\hline \multirow[t]{3}{*}{$\mathrm{BD}\left(\mathrm{g} / \mathrm{cm}^{3}\right)$} & $0-10 \mathrm{~cm}$ & 1.60 & 1.65 & 1.58 & 1.52 & 1.52 & 1.48 \\
\hline & $10-20 \mathrm{~cm}$ & 1.68 & 1.72 & 1.67 & 1.61 & 1.64 & 1.57 \\
\hline & $20-30 \mathrm{~cm}$ & 1.72 & 1.78 & 1.71 & 1.65 & 1.68 & 1.62 \\
\hline \multirow[t]{3}{*}{ SOM (kg/ha) } & $0-10 \mathrm{~cm}$ & 5516 & 12,800 & 14,981 & 17,388 & 19,653 & 21,943 \\
\hline & $10-20 \mathrm{~cm}$ & 3475.6 & 6820 & 8349 & 10,269 & 8764 & 11,368 \\
\hline & $20-30 \mathrm{~cm}$ & 2372 & 3989 & 4717 & 4835 & 4344 & 6144 \\
\hline \multirow[t]{3}{*}{ SOC (kg/ha) } & $0-10 \mathrm{~cm}$ & 3200 & 7425 & 8690 & 9982 & 11,400 & 12,728 \\
\hline & $10-20 \mathrm{~cm}$ & 2016 & 3956 & 4843 & 5957 & 5084 & 6594 \\
\hline & $20-30 \mathrm{~cm}$ & 1376 & 2314 & 2736 & 2805 & 2520 & 3564 \\
\hline \multirow[t]{3}{*}{ TN (kg/ha) } & $0-10 \mathrm{~cm}$ & 160 & 247.5 & 379.2 & 425.6 & 501.6 & 503 \\
\hline & $10-20 \mathrm{~cm}$ & 100.8 & 137.6 & 233.8 & 112 & 131 & 141 \\
\hline & $20-30 \mathrm{~cm}$ & 51.6 & 53.4 & 102.6 & 132 & 67 & 81 \\
\hline \multirow[t]{3}{*}{$\mathrm{TP}$ (kg/ha) } & $0-10 \mathrm{~cm}$ & 128 & 132 & 142 & 167 & 167 & 207 \\
\hline & $10-20 \mathrm{~cm}$ & 84 & 70.52 & 76.82 & 80.5 & 98 & 109 \\
\hline & $20-30 \mathrm{~cm}$ & 17.2 & 40.94 & 42.75 & 42.9 & 33.6 & 38.88 \\
\hline \multirow[t]{3}{*}{ MBC (kg/ha) } & $0-10 \mathrm{~cm}$ & 156.8 & 189.75 & 860.32 & 939.8 & 943.58 & 1039 \\
\hline & $10-20 \mathrm{~cm}$ & 70.56 & 104.6 & 401.8 & 420.76 & 502.67 & 614.21 \\
\hline & $20-30 \mathrm{~cm}$ & 37.84 & 49.66 & 210 & 213.84 & 250.17 & 307.89 \\
\hline
\end{tabular}


There was an increase in bulk density between 2 and 19 years at $0-10$ to $10-20$ and $20-30 \mathrm{~cm}$ depth by 5 to $8 \%$ and 6 to $10 \%$. The TN declined across soil depth from 37 to $68 \%$ and $72-84 \%$, and TP by $34-87 \%$ and $47-81 \%$, respectively.

The nature of the soils has an important affect on the amount of carbon it holds. Rice (2002, http://www.geotimes.org/jan02/ featurecarbon.html) reported that soil water content is an important factor in this respect, as optimal microbial activity occurs at or near field capacity (the maximum amount of water that soil can hold against gravity). As soil becomes waterlogged, decomposition slows and becomes less complete. Decomposition also slows as soils dry.

Soil texture is also important as silt and clay can promote the formation of organic-mineral complexes. The close relationship between soil structure and soil organic carbon (Han et al., 2010) involves two processes: (1) organic carbon chemically bonds to clay surfaces, which slows degradation as clays with high adsorption capacities (e.g. montmorillonite) retain the organic molecules, and (2) soils with higher clay contents have potential to form aggregates, which trap organic carbon and physically protect it from microbial degradation (Bolan et al., 2012; Rice, 2002, http://www. geotimes.org/jan02/featuree_carbon.html).

The bulk density of a soil can be used to calculate the total quantities of carbon sequestered at a particular time and soil depth. Krull et al. (2001) stated that almost all organic carbon in soil is located in the pores between mineral particles, either as discrete particles or as molecules adsorbed onto the mineral surfaces. Soil architecture influences the biological stability of organic materials by influencing water and oxygen availability, the entrapment and isolation from decomposers, and through the dynamics of soil aggregation.

In the present study, bulk density was found to show an inverse relation with organic carbon and microbial biomass C (Figs. 2 and 3 ). The equations are:

Organic carbon $(\mathrm{kg} / \mathrm{ha})=-61.918$ bulk density

$+123.6\left(R^{2}=0.5932\right)$

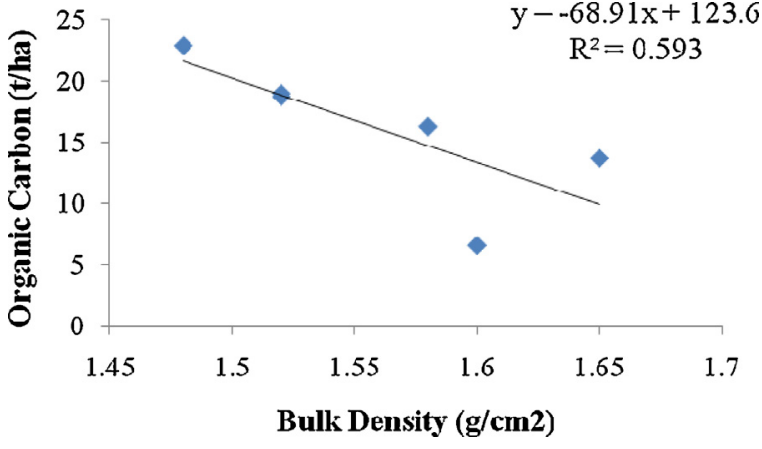

Fig. 2. Relation between bulk density and soil organic C.

Microbial biomass $\mathrm{C}(\mathrm{kg} / \mathrm{ha})=-10.389$ bulk density

$$
+17.408 \quad\left(R^{2}=0.8036\right)
$$

\subsection{Plant biomass}

The growth of plants was measured by recording the variation in the mean girth, diameter, height, wood density and biomass of plant species in at the study sites along with re-vegetation age of 19 years are shown in Table 3.

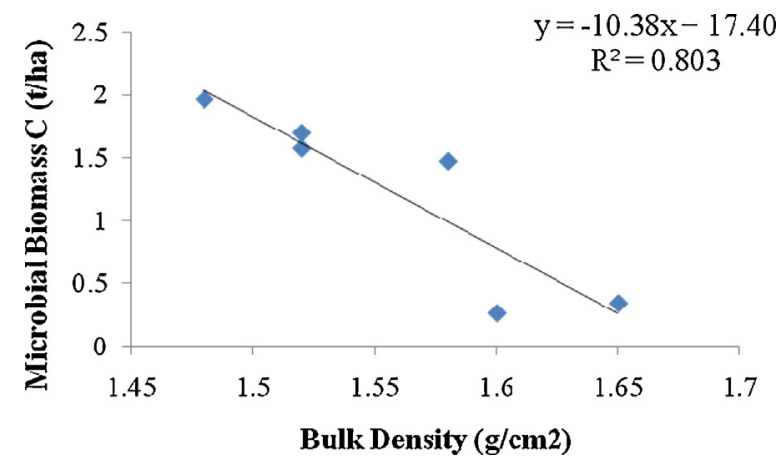

Fig. 3. Relation between bulk density and microbial biomass $\mathrm{C}$.

Table 3

Variations of mean girth, diameter, height, wood density and biomass of plant species in re-vegetated mine spoils.

\begin{tabular}{|c|c|c|c|c|c|c|c|c|}
\hline Sl. no. & Age (years) & Attributes & Tree & Under story & Litter mass & $\begin{array}{l}\text { Above ground } \\
\text { biomass }\left(\mathrm{g} / \mathrm{cm}^{2}\right)\end{array}$ & $\begin{array}{l}\text { Below ground } \\
\text { biomass }\left(\mathrm{g} / \mathrm{cm}^{2}\right)\end{array}$ & $\begin{array}{l}\text { Total biomass } \\
\left(\mathrm{g} / \mathrm{cm}^{2}\right)\end{array}$ \\
\hline 1 & & Biomass & 2.48 & - & 0.56 & 3.04 & 0.45 & 3.50 \\
\hline 2 & 2 & C Seq (t/ha) & 1.24 & - & 0.28 & 1.52 & 0.23 & 1.75 \\
\hline 3 & & $\mathrm{CO}_{2} \mathrm{E}(\mathrm{t} / \mathrm{ha})$ & 4.55 & - & 1.03 & 5.58 & 0.83 & 6.41 \\
\hline 4 & & Biomass & 7.67 & - & 1.82 & 9.49 & 1.42 & 10.91 \\
\hline 5 & 4 & C Seq (t/ha) & 3.84 & - & 0.91 & 4.75 & 0.71 & 5.45 \\
\hline 6 & & $\mathrm{CO}_{2} \mathrm{E}(\mathrm{t} / \mathrm{ha})$ & 14.07 & - & 3.34 & 17.41 & 2.60 & 20.0 \\
\hline 7 & & Biomass & 20.85 & 3.39 & 3.09 & 27.33 & 3.96 & 31.30 \\
\hline 8 & 10 & C Seq (t/ha) & 10.43 & 1.70 & 1.55 & 13.68 & 1.98 & 15.65 \\
\hline 9 & & $\mathrm{CO}_{2} \mathrm{E}(\mathrm{t} / \mathrm{ha})$ & 38.23 & 6.22 & 5.67 & 50.12 & 7.27 & 57.38 \\
\hline 10 & & Biomass & 36.40 & 5.38 & 4.29 & 46.07 & 5.85 & 51.91 \\
\hline 11 & 14 & C Seq (t/ha) & 18.20 & 2.69 & 2.15 & 23.04 & 2.92 & 25.96 \\
\hline 12 & & $\mathrm{CO}_{2} \mathrm{E}(\mathrm{t} / \mathrm{ha})$ & 66.72 & 9.86 & 7.87 & 84.45 & 10.72 & 95.18 \\
\hline 13 & & Biomass & 44.19 & 6.80 & 4.80 & 55.79 & 7.43 & 63.22 \\
\hline 14 & 16 & C Seq (t/ha) & 22.09 & 3.40 & 2.40 & 27.89 & 3.72 & 31.61 \\
\hline 15 & & $\mathrm{CO}_{2} \mathrm{E}(\mathrm{t} / \mathrm{ha})$ & 81.01 & 12.47 & 8.80 & 102.28 & 13.63 & 115.91 \\
\hline 16 & & Biomass & 63.13 & 9.75 & 5.60 & 78.48 & 10.57 & 89.05 \\
\hline 17 & 19 & C Seq (t/ha) & 31.57 & 4.88 & 2.80 & 39.25 & 5.28 & 44.52 \\
\hline 18 & & $\mathrm{CO}_{2} \mathrm{E}(\mathrm{t} / \mathrm{ha})$ & 115.74 & 17.88 & 10.27 & 143.89 & 19.37 & 163.26 \\
\hline
\end{tabular}


Plant biomass increased aboveground, belowground and in total by $2481 \%$ (26 times), $2248 \%$ (23 times) and 2444\% (25 times), respectively between 2 and 19 years.

The increase in below ground biomass with time may be due to increase in leaf litter fall and its decomposition, higher root turn over leading to increased organic matter. Rhoades (2001) hypothesized that increasing spoil depth will enhance rooting volume and total fines, thereby increasing above- and below-ground production. They also proposed that the spoil source chemistry and nutrient availability might also alter the above- and below-ground production.

In disturbed habitats, the natural recovery of plant and animal species is slow. However, afforestation with the use, of amendments, takes less time to establish a native forest ecosystem. Plantations can reverse degradation by stabilizing soils through development of extensive root systems. Tripathi and Singh (2008) reported that re-vegetated mine spoils have the potential to restore both soil microbial biomass and plant biomass.

The age of re-vegetated mine spoil is very important, as the increase in plant biomass, organic matter and, $\mathrm{MBC}$ along with time to maturity can yield woody trees with a carbon sequestration potential compared to the young trees and herb or shrub species.

The SOC arising from woody vegetation is also more recalcitrant than that from herbaceous vegetation (due to its higher concentration of aliphatic root suberin, waxes, glycerides, lignin and tannins) (Filley et al., 2008). Dean et al. (2012) reported 95\% higher C levels in woody trees when compared to herbaceous plants, due to their deeper roots.

Below ground biomass provides a direct input of organic matter and mineral nutrients in soil through exudation and upon mortality (Tripathi and Singh, 2009). Below ground biomass was also found to be positively correlated $\left(R^{2}=8576, P<0.05\right)$ with the soil organic $C$ in all sites (Fig. 4). The regression equation is:

Below ground biomass $\left(\mathrm{g} \mathrm{m}^{-2}\right)=9.4402$

$$
+1.3679 \text { soil organic }(\mathrm{Ct} / \mathrm{ha}) \quad\left(R^{2}=0.8576\right)
$$

\subsection{Soil organic carbon}

The values of soil organic carbon (SOC) and soil organic matter (SOM) contents in re-vegetated mine spoils are shown in Table 2.

An increase in organic carbon content of soil by $298 \%$ (4 times) occurred along the re-vegetation age gradient. With increasing depth from $0-10$ to $10-20$ and $20-30 \mathrm{~cm}$, there was a decline in soil organic carbon content of 37 to $57 \%$ and 48 to $74 \%$, from $0-10$ to $10-20$ and to $20-30 \mathrm{~cm}$ depths, respectively.

Increasing a soils organic matter also increases the thickness of a soil as organic matter has a density around one quarter that of the mineral soil. An increase in organic matter therefore usually is accompanied by a reduction of a soils bulk density (Tunstall, 2010; www.eric.com.au).

The nature of various organo-mineral associations and their location and distribution within soil aggregates determine the extent of physical protection and chemical stabilization of SOC (Gjisman and Sanze, 1998). Clay sized organo-mineral complexes

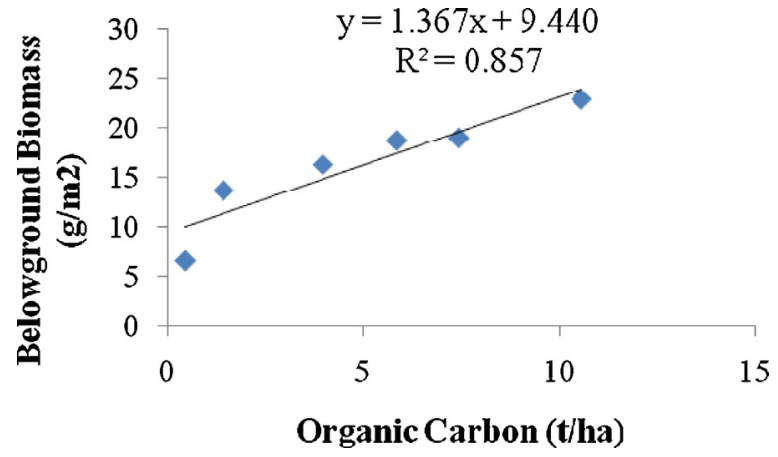

Fig. 4. Relation between organic carbon and belowground biomass.

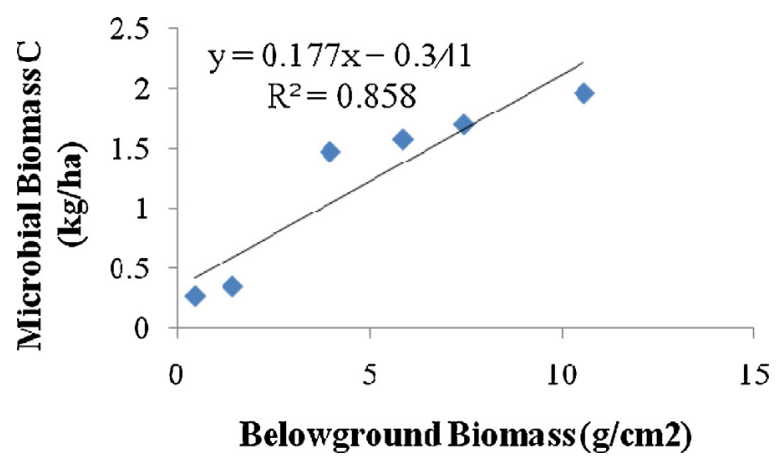

Fig. 5. Relation between belowground biomass and microbial biomass $C$.

often show greater accumulations and subsequently more rapid loss rates than in silt sized particles, indicating a higher stability of silt-SOC (Christensen, 1996). The same mechanisms also play major roles in the stabilization and retention of SOC in mine soil. Schlesinger (1990) documented long-term rates of carbon storage from $0.2 \mathrm{~g} \mathrm{C} \mathrm{m}^{-2}$ year $^{-1}$ in some polar deserts to $\mathrm{C} \mathrm{m}^{-2}$ year ${ }^{-1}$ over all ecosystems (Post and Kwon, 2000).

\subsection{Microbial biomass $C$}

The values recorded for soil microbial biomass carbon (MBC) in re-vegetated mine spoils are shown in Table 4.

Microbial biomass C was found in the range $157-1040 \mathrm{~kg} / \mathrm{ha}$, showing an increase by 563\% (6.6 times) along an age gradient. MBC has shown a decline of 55-76\% and 55-77\% with increasing depth of soil from $0-10 \mathrm{~cm}$ to $10-20$ and $20-30 \mathrm{~cm}$, respectively.

Plant-microbe interaction and $\mathrm{C}, \mathrm{N}$ cycles also play a major role in soil carbon sequestration (Macdonald et al., 2011). Plants provide $C$ for microbial activity and soil $C$ sequestration through rhizodeposition and litter fall, while microbial activities directly affect SOC concentrations and indirectly influence plant $\mathrm{C}$ accumulation through its control over the $\mathrm{N}$ cycle.

Soil microbial processes strongly regulate ecosystem net primary production (Cleveland et al., 2006). Most of the nutrient requirements of plants are met by the mineralization of soil organic nutrients by the microbial community (Paul and Clark, 1996). The

Table 4

Microbial biomass $C$ in re-vegetated mine spoils.

\begin{tabular}{|c|c|c|c|c|c|c|c|}
\hline \multirow{2}{*}{$\begin{array}{l}\text { Sites } \\
\text { Parameters }\end{array}$} & & \multicolumn{6}{|c|}{ Age of re-vegetated mine spoils (years) } \\
\hline & & 02 & 04 & 10 & 14 & 16 & 19 \\
\hline \multirow[t]{3}{*}{ MBC (kg/ha) } & $0-10 \mathrm{~cm}$ & 156.8 & 189.75 & 860.32 & 939.8 & 943.58 & 1039.7 \\
\hline & $10-20 \mathrm{~cm}$ & 70.56 & 104.6 & 401.8 & 420.76 & 502.67 & 614.21 \\
\hline & $20-30 \mathrm{~cm}$ & 37.84 & 49.66 & 210 & 213.84 & 250.17 & 307.89 \\
\hline
\end{tabular}




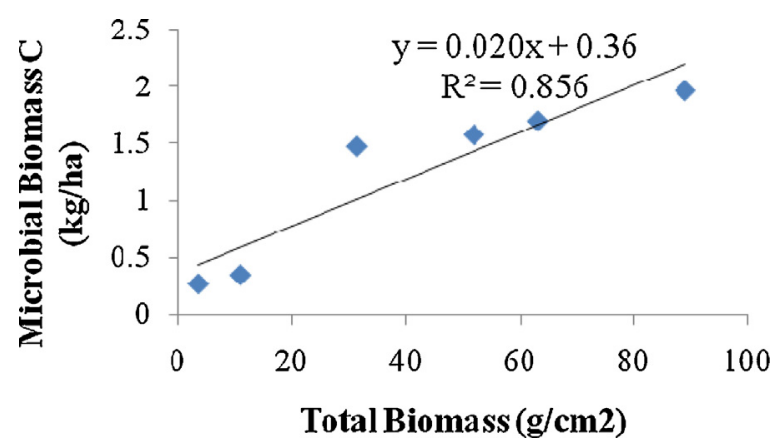

Fig. 6. Relation between total biomass and microbial biomass $C$.

contribution of soil microbial biomass to carbon cycling, however, is seriously underestimated and its turnover poorly understood. Microbial biomass is the most important parameter used to characterize biological soil processes, because it is 'a primary catalyst of biogeochemical processes as well as an energy and nutrient reservoir' (Kutsch et al., 2010). It has been used, although to a much lesser extent, as a measure for the carbon turnover potential of soils, and as microbes have a high tolerance towards stress conditions (as found in mine impacted soils) they are well equipped to survive and remain active enhancing recovery, unless that is the stress is so great that it is lethal or forces dormancy (Farrar and Reboli, 1999; Suzina et al., 2004).

Microbial biomass, while a small portion of SOC, mediates the transfer of SOC among inputs, low fraction organic carbon and organo-mineral high fraction organic carbon. As a result, rates of transfer and transformation are influenced by biologically important factors including soil moisture and soil temperature (Post and Kwon, 2000).

In the present study microbial $C$ was positively related to the belowground biomass and total plant biomass $(P<0.05)$ (Figs. 5 and 6).
Microbial C $(\mathrm{kg} / \mathrm{ha})=0.3419$

$$
+0.1772 \text { belowground biomass }\left(\mathrm{g} \mathrm{m}^{-2}\right) \quad\left(R^{2}=0.8584\right)
$$

Microbial C $(\mathrm{kg} / \mathrm{ha})=0.36$

$$
+0.0206 \text { total biomass }\left(\mathrm{g} \mathrm{m}^{-2}\right) \quad\left(R^{2}=0.856\right)
$$

\subsection{Carbon budget in re-vegetated mine spoils}

The total carbon contents for the soils are shown in Table 5. The carbon content was considered to be about $50 \%$ of the amount of total biomass present, both above and below ground. The biomass, soil organic carbon and soils microbial biomass carbon was found to be in the range of $1.52-39.25,0.23-5.28$, 6.6-22.9,0.265-1.961 T/ha, respectively.

The re-vegetated mine spoils showed increased biomass carbon content by $2444 \%$ (25 times) along an age gradient. The maximum total carbon sequestration in all the components viz. biomass, soil and microbial biomass to 19 years was $69.39 \mathrm{~T} /$ ha comprising: total plant biomass, soil organic carbon and soil microbial biomass of $44.52 \mathrm{~T} / \mathrm{ha}, 22.9 \mathrm{~T} /$ ha and $1.961 \mathrm{~T} /$ ha, respectively. The total sequestered carbon increased by $705 \%$ directly due to the increase in plant biomass.

These findings clearly indicated that the re-vegetation process substantial enhances the amount of carbon stored by plants, with carbon transfer being facilitated by leaf litter, root decay and root exudates (Tripathi et al., 2014). Similar observations by Akala and Lal (2000) showed reclaimed mine soil can sequester SOC up to $30 \mathrm{Mg} \mathrm{Cha}{ }^{-1}$ over a 25 -year period (Table 6 ).

The findings of this study also show that the $\mathrm{CO}_{2}$ equivalent removed from the atmosphere into biomass (and thus, sequestrated into the soil) can be budgeted following re-vegetation. The carbon budget for different ecosystems is shown in Table 7. Fig. 7 shows a schematic of the process of reclaiming mine spoil.

Table 5

\begin{tabular}{|c|c|c|c|c|c|c|c|c|c|}
\hline Study sites & & $\begin{array}{l}\text { Total } \\
\text { aboveground } \\
\text { biomass (T/ha) }\end{array}$ & $\begin{array}{l}\text { C seq (T/ha) } \\
\text { (A) }\end{array}$ & $\begin{array}{l}\text { Root } \\
\text { biomass } \\
\text { (T/ha) }\end{array}$ & $\begin{array}{l}\text { C seq (T/ha) } \\
\text { (B) }\end{array}$ & $\begin{array}{l}\text { Organic C } \\
(\mathrm{T} / \mathrm{ha})(\mathrm{C})\end{array}$ & $\begin{array}{l}\operatorname{MBC}(T / h a) \\
\text { (D) }\end{array}$ & $\begin{array}{l}\text { Total C seq } \\
(T / h a) \\
(A+B+C+D)\end{array}$ & $\begin{array}{l}\mathrm{CO}_{2} \mathrm{E} \\
\text { (T/ha) }\end{array}$ \\
\hline \multirow[t]{6}{*}{ NCL Jayant } & 2 years & 3.04 & 1.52 & 0.45 & 0.23 & 6.6 & 0.265 & 8.615 & 31.61 \\
\hline & 4 years & 9.49 & 4.75 & 1.42 & 0.71 & 13.7 & 0.344 & 19.504 & 71.58 \\
\hline & 10 years & 27.33 & 13.68 & 3.96 & 1.98 & 16.3 & 1.472 & 33.432 & 122.69 \\
\hline & 14 years & 46.07 & 23.04 & 5.85 & 2.92 & 18.74 & 1.574 & 46.274 & 169.82 \\
\hline & 16 years & 55.79 & 27.89 & 7.43 & 3.72 & 19.00 & 1.69 & 52.31 & 191.96 \\
\hline & 19 years & 78.48 & 39.25 & 10.57 & 5.28 & 22.9 & 1.961 & 69.391 & 254.66 \\
\hline
\end{tabular}

Carbon storage as $\mathrm{CO}_{2}$ equivalent in soil.

Table 6

\begin{tabular}{|c|c|c|c|c|}
\hline Land use & Depth $(\mathrm{cm})$ & Period (years) & $\begin{array}{l}\text { Rate of } \mathrm{C} \text { sequestration } \\
\left(\mathrm{Mg} \mathrm{ha}^{-1} \text { year }^{-1}\right)\end{array}$ & Reference \\
\hline Grass & $\begin{array}{l}0-15 \\
0-15 \\
0-15 \\
-\end{array}$ & $\begin{array}{r}11 \\
25 \\
47 \\
-45\end{array}$ & $\begin{array}{l}3.1 \\
0.5-3.1 \\
0.53 \\
0.13\end{array}$ & $\begin{array}{l}\text { Akala and Lal (2000) } \\
\text { Akala and Lal (2001) } \\
\text { Shukla and Lal (unpublished) } \\
\text { Wali (1999) }\end{array}$ \\
\hline Forest & $\begin{array}{l}0-15 \\
0-15 \\
- \\
0-10\end{array}$ & $\begin{array}{r}14 \\
21 \\
- \\
40\end{array}$ & $\begin{array}{l}2.6 \\
0.7-2.3 \\
4.0 \\
0.58\end{array}$ & $\begin{array}{l}\text { Akala and Lal (2000) } \\
\text { Akala and Lal (2001) } \\
\text { Burger (2004) } \\
\text { Sourkova et al. (2005) }\end{array}$ \\
\hline Re-vegetated mine wasteland & $0-30$ & 19 & 3.57 & Present study \\
\hline
\end{tabular}

Carbon storage in reclaimed mine soil. 
Table 7

Carbon budgets for grassland, forest and agricultural ecosystems.

\begin{tabular}{|c|c|c|c|c|}
\hline Type of ecosystem & Location & $\begin{array}{l}\text { Method of budget } \\
\text { estimation }\end{array}$ & $\mathrm{C}$ budget1 $\left(\mathrm{gC} \mathrm{m}^{-2}\right.$ year $\left.^{-1}\right)$ & References \\
\hline \multicolumn{5}{|l|}{ Grassland ecosystem } \\
\hline Grassland ecosystem (Miscanthus sinensis) & Nagano, Japan & Ecological method & -100 to -56 & Yazaki et al. (2004) \\
\hline Pasture & New Zealand & $\begin{array}{l}\text { Mass balance and } \\
\text { modelling }\end{array}$ & -414 & Tate et al. (2000) \\
\hline Grassland & Cork, Ireland & Eddy covariance & +236 & Leahy et al. (2004) \\
\hline \multirow[t]{2}{*}{ Grass (200 kg Nha ${ }^{-1}$ ) } & Uppsala, Sweden & Ecological method & +140 & Paustin et al. (1990) \\
\hline & Texas, USA & $\begin{array}{l}\text { Bowen ratio/energy } \\
\text { balance }\end{array}$ & +50 to +80 & Dugas et al. (1999) \\
\hline \multirow{2}{*}{ Tall-grass prairie } & Oklahoma, USA & Eddy covariance & -8 & Suyker and Verma (2001) \\
\hline & Wisconsin, USA & Difference method2 & -410 to +70 & Brye et al. (2002) \\
\hline Mixed-grass prairie & North Dakota, USA & $\begin{array}{l}\text { Bowen ratio/energy } \\
\text { balance (soil flux) }\end{array}$ & +31 & Frank and Dugas (2001) \\
\hline Moist-mixed prairie & Alberta, Canada & Eddy covariance & -18 to +21 & Flanagan et al. (2002) \\
\hline Meadow & Moscow, Russia & Ecological method & +387 & Larionova et al. (1998) \\
\hline \multicolumn{5}{|l|}{ Forest ecosystem } \\
\hline Aspen-lime-birch & Moscow, Russia & Ecological method & +135 & Larionova et al. (1998) \\
\hline Scots pine forest, $40 \mathrm{y}$ old (Pinus sylvestris) & Southern Finland & Eddy covariance & +228 & Kolari et al. (2004) \\
\hline French pine forest (Pinus pinaster) & Les Landes, France & Eddy covariance & -200 to -340 & Kowalski et al. (2003) \\
\hline Boreal and temperate forest of Ontario & Ontario, Canada & Model: CBM-CFS2 & -40 & Liu et al. (2006) \\
\hline Ontario's forest ecosystem & Ontario, Canada & Model: CBM-CFS2 & -43 & Peng et al. (2000) \\
\hline Indigenous forest & New Zealand & $\begin{array}{l}\text { Mass balance and } \\
\text { modelling }\end{array}$ & -136 & Tate et al. (2000) \\
\hline \multicolumn{5}{|l|}{ Agricultural ecosystem } \\
\hline Mix agricultural crops & Denmark & Eddy covariance & -31 & Soegaard et al. (2003) \\
\hline Barley - no fertilizer & Uppsala, Sweden & Difference method2 & -20 & Paustin et al. (1990) \\
\hline$-120 \mathrm{~kg} \mathrm{~N}$ & Uppsala, Sweden & Difference method2 & +10 & Paustin et al. (1990) \\
\hline Corn - continuous & Ohio, USA & $\begin{array}{l}\text { Cropland ecosystem } \\
\text { model C (CEM) }\end{array}$ & +26 & Evrendilek and Wali (2004) \\
\hline - chisel plowed, fertilized & Wisconsin, USA & Difference method2 & -90 to +590 & Brye et al. (2002) \\
\hline - no till, fertilized & Wisconsin, USA & Difference method2 & -210 to +430 & Brye et al. (2002) \\
\hline No till corn - soybean & North Central USA & Eddy covariance & +90 & Hollinger et al. (2005) \\
\hline Re-vegetated mine waste land & Dry tropical ecosystems, India & Ecological method & 354.79 & Present Study \\
\hline
\end{tabular}

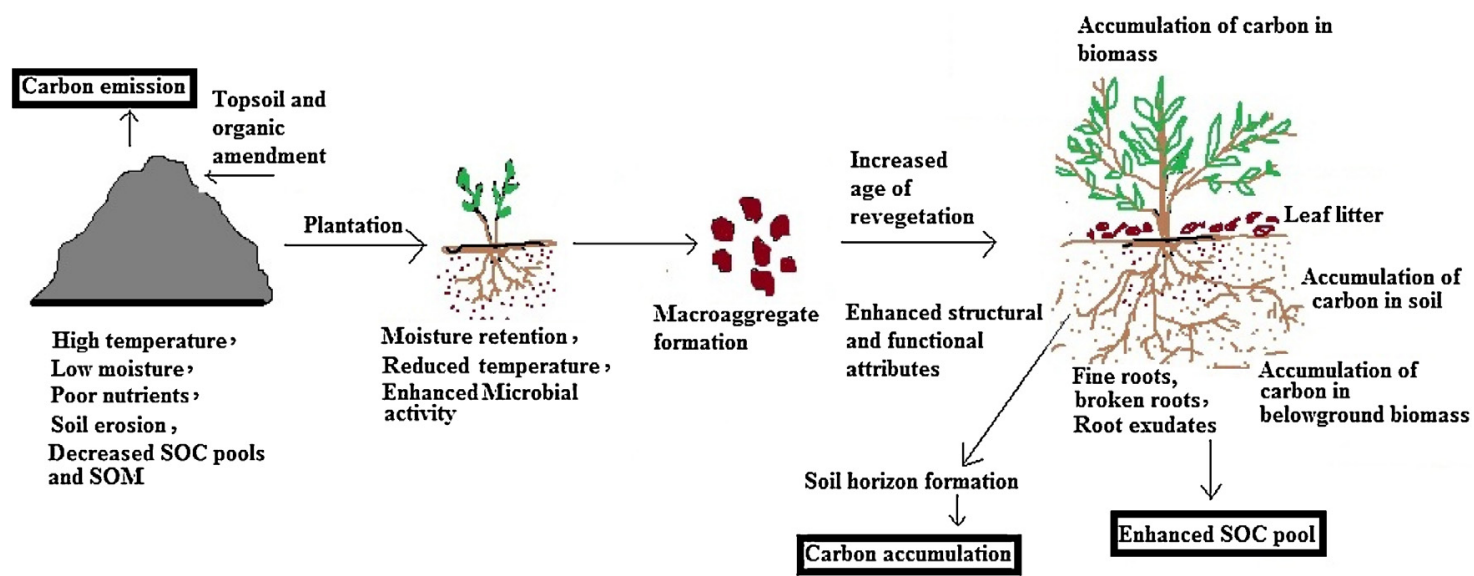

Fig. 7. The process of reclaiming mine spoil.

\section{Conclusions}

The re-vegetation of mine spoil/overburden can return land to a useful state. The reconstruction of a soil depends on the introduction of vegetation, which over time will improve soil physical, chemical and biological properties, which promote the recovery of ecosystem function that can thrive and be sustainable. The consequential sequestration of carbon in re-vegetated mine spoil is significant as SOC persists over long periods.

The results of the present study clearly indicate that mine spoil can act as a significant sink for atmospheric carbon dioxide $\left(\mathrm{CO}_{2}\right)$, and that careful management of the rejuvenation process could be used as a means to maximize the carbon locked in soil. Potential to use the carbon budget as an offset against the emissions of the mining activity itself exists. Future studies should be directed at coordinated restoration of mine spoil to specifically enhance the amount of SOC produced, including the use of, for example, amendments such as mulch and biochar.

There are many factors that determine the direction and rate of change in SOC content in re-vegetated soil. In mine spoils, the SOC can be increased directly from organic matter, but its rate of decomposition at depth is important. The nature of organic matter input, its placement (deeper or shallower), its mixing with soil organisms, and the consequent enhancement of physical protection via intra-aggregate or organo-mineral complexes are important variables. The conditions that favour these processes can be generated in the mine spoils through re-vegetation as can be seen in this work. 
One management strategy is ecological restoration by increasing the establishment of native species, particularly with high carbon stock in biomass and late successional species. Once the reclamation plan is complete and vegetation has established, the assessment of the reclaimed site is necessary to evaluate the success of reclamation.

The evaluation of carbon sequestration potential of re-vegetated mine spoils along an age gradient can evince the reclamation success, as it gives a clear picture of all the physico-chemical characteristics of soil and plant biomass. A long-term study on productivity of re-vegetated mine spoils is needed to identify sustainable management options and evaluate the carbon budget over a longer period of time.

\section{Acknowledgements}

The authors acknowledge the DST, Ministry of Science and Technology, and Ministry of Coal, India for financial help and CSIR-CIMFR for enabling to conduct the research.

\section{References}

Akala, V.A., Lal, R., 2000. Potential of mine land reclamation for soil organic C sequestration in Ohio. Land Degrad. Dev. 11, 289-297.

Akala, V.A., Lal, R., 2001. Soil organic pools and sequestration rates in reclaimed mine soils in Ohio. J. Environ. Qual. 30, 2098-2104.

Anderson, J.D., Stahl, P.D., Ingram, L.J., 2004. Influence of mineland reclamation practices on microbial community recovery and soil organic carbon accumulation. In: Barnhisel, R.I. (Ed.), Proceedings of a Joint Conference of American Society of Mining and Reclamation and 21st Annual National Conference and 25th West Virginia Surface Mine Drainage Task Force Symposium. American Society of Mining and Reclamation, Lexington, KY, pp. 74-86.

Atjay, G.L., Ketner, P., Duvignead, P., 1979. Terrestrial primary production and phytomass. In: Bolin, B., Degens, E.T., Kempe, S. (Eds.), The Global Carbon Cycle. Wiley and Sons, New York, pp. 129-182.

Barnhisel, R.I., Hower,J.M., 1997. Coal surface mine reclamation in the eastern United States: the revegetation of disturbed lands to hayland/pastureland or cropland. In: Sparks, D.L. (Ed.), Advances in Agronomy. Academic Press, New York, NY, pp. 233-237.

Bradshaw, A., 1997. Restoration of mine lands-using natural processes. Ecol. Eng. 8, 255-269.

Brady, N.C., 1985. The Nature and Properties of Soils, 8th ed. Eurasia Publishing House, New Delhi.

Bolan, N.S., Kunhikrishnan, A., Choppala, G.K., Thangarajan, R., Chung, J.W., 2012. Stabilization of carbon in composts and biochars in relation to carbon sequestration and soil fertility. Sci. Total Environ. 424, 264-270.

Brown, S., Lugo, A.E., 1982. The storage and production of organic matter in tropical forests and their role in the global carbon cycle. Biotropica 14, 161-187.

Brye, K.R., Gower, S.T., Norman, J.M., Bundy, L.G., 2002. Carbon budgets for a prairie and agro-ecosystems: effects of land use and inter annual variability. Ecol. Appl. 12, 962-979.

Burger, J.A., 2004. Restoring forests on mined land in the Appalachians: results and outcomes of a 20-year research program. In: Proceedings of the 21st Annual Meeting of the American Society for Mining and Reclamation, April 18-22, Morgantown, WV, pp. 552-563.

Canadell, J.G., Le Quere, C., Raupach, M.R., Field, C.B., Buitenhuis, E.T., Ciais, P., Conway, T.J., Gillett, N.P., Houghton, R.A., Marland, G., 2007. Contributions to accelerating atmospheric $\mathrm{CO}_{2}$ growth from economic activity, carbon intensity, and efficiency of natural sinks. Proc. Natl. Acad. Sci. U. S. A. 104, 18866-18870, Copyright (2007) National Academy of Sciences, U.S.A.

Cannell, M.G.R., Milne, R., 1995. Carbon pools and sequestration in forest ecosystems in Britain. Forestry 68, 361-378.

Christensen, B.T., 1996. Carbon in primary and secondary organo-mineral complexes. In: Carter, M.R., Stewart, B.A. (Eds.), Structure and Organic Matter Storage in Agricultural Soil, Adv. Soil Sci. CRC Lewis Publishers, Boca Raton, pp. 97-166.

Cleveland, C.C., et al., 2006. Soil microbial dynamics in Costa Rica: seasonal and biogeochemical constraints. Biotropica 36 (2), 184-195.

Dakora, F.D., Phillips, D.A., 2000. Root exudates as mediators of mineral acquisition in low-nutrient environments. In: Adu-Gyamfi, J.J. (Ed.), Food Security in Nutrient-Stressed Environments: Exploring Plants' Genetic Capabilities. Kluwer, Dordrecht.

Dean, C., Roxburgh, S.H., Harper, R.J., Eldridge, D.J., Watson, I.W., Wardell-Johnson, G.W., 2012. Accounting for space and time in soil carbon dynamics in timbered rangelands. Ecol. Eng. 38, 51-64.

Dixon, R.K., Brown, S., Solomon, R.A., Trexler, M.C., Wisniewski, J., 1994. Carbon pools and flux of global forest ecosystems. Science 263, 185-190.

Dugas, W.A., Heuer, M.L., Mayeux, H.S., 1999. Carbon dioxide fluxes over Bermuda grass, native prairie, and sorghum. Agric. For. Meteorol. 93, 121-139.
Evrendilek, F., Wali, M.K., 2004. Changing global climate: historical carbon and nitrogen budgets and projected responses of Ohio's cropland ecosystems. Ecosystems 7, 381-392.

FAO, 2001. State of the World's Forests - 2001. FAO-Information Division, Vialle delle terme di Caracalla, 00100, Rome, Italy.

Farrar, W., Reboli, A., 1999. The genus Bacillus: medical. In: Dworkin, M. (Ed.), The Prokaryotes: An Evolving Electronic Resource for the Microbiological Community, release 3.0. , 3rd ed. Springer-Verlag, New York, NY, USA.

Filley, T.R., Boutton, T.W., Liao, J.D., Astrow, J.D., Gamblin, D.E., 2008. Chemical changes to non-aggregated particulate soil organic matter following grasslandto-woodland transition in subtropical savanna. J. Geophys. Res. 113, http://dx. doi.org/10.1029/2007JG000564.

Flanagan, L.B., Wever, L.A., Carlson, P.J., 2002. Seasonal and interannual variation in carbon dioxide exchange and carbon balance in northern temperate grassland. Glob. Change Biol. 8, 599-615.

Frank, A.B., Dugas, W.A., 2001. Carbon dioxide fluxes over a northern, semiarid, mixed grass prairie. Agric. For. Meteorol. 108, 317-326.

Gjisman, A.J., Sanze, I.I., 1998. Soil organic matter pools in volcanic ash soil under fallow or cultivation with applied chicken manure. Eur. J. Soil Sci. 49, 427-436.

Han, K.H., Ha, S.G., Jang, B.C., 2010. Aggregate stability and soil carbon storage as affected by different land use practices. In: Proc. of Int. Workshop on Evaluation and Sustainable Management of Soil Carbon Sequestration in Asian Countries, Bogor, Indonesia, September 28-29.

Hollinger, S.E., Bernacchi, C.J., Meyers, T.P., 2005. Carbon budget of mature no-till ecosystem in North Central Region of the United States. Agric. For. Meteorol. 130, 59-69 https://conference.ifas.ufl.edu/citrus10/./1610\%20Spreen.pdf.

IPCC, 2001. Climate Change 2001: The Scientific Basis. Contribution of working group I to the Third Assessment Report of the Intergovernmental panel on Climate Change. Cambridge University Press, Cambridge.

Jackson, M.L., 1958. Soil Chemical Analysis. Prentice Hall, Englewood Cliffs.

Jenkinson, D.S., Powlson, D.S., 1976. The effects of biocidal treatment on metabolism in soil - V. A method for measuring soil biomass. Soil Biol. Biochem. 8, 209-213.

Kolari, P., Pumpanen, J., Rannik, U., Ilvesniemi, H., Hari, P., Berninger, F., 2004. Carbon balance of different aged Scots pine forests in Southern Finland. Glob. Change Biol. 10, 1106-1119.

Kowalski, S., Sartore, M., Burlett, R., Berbigier, P., Loustau, D., 2003. The annual carbon budget of a French pine forest (Pinus pinaster) following harvest. Glob. Change Biol. 9, 1051-1065.

Krull, E., Baldock, J., Skjemstad, J., 2001. Soil texture effects on decomposition and soil carbon storage. In: NEEWorkshop Proceedings, 18-20 April 2001. CRC for Greenhouse Accounting, CSIRO Land and Water Australia.

Kutsch, W.L., Tryggve, P., Schrumpf, M., Moyano, F.E., Mund, M., Andersson, S., Schulze, E.D., 2010. Heterotrophic soil respiration and soil carbon dynamics in the deciduous Hainich forest 30 obtained by three approaches. Biogeochemistry, http://dx.doi.org/10.1007/s10533-010-9414-9.

Lal, R., 2004. Soil carbon sequestration to mitigate climate change. Geoderma 123, $1-22$.

Larionova, A.A., Yermolayev, A.M., Blagodatsky, S.A., Rozanov, I.V., Orlinsky, D.B., 1998. Soil respiration and carbon balance of gray forest soils as affected by land use. Biol. Fertil. Soils 27, 251-257.

Leahy, P., Kiely, G., Scanlon, T.M., 2004. Managed grasslands: a greenhouse gas sink or source? Geophys. Res. Lett. 31, L20507, http://dx.doi.org/10.1029/.

Liu, J., Liu, S., Loveland, T.R., 2006. Temporal evolution of carbon budgets of the Appalachian forests in the U.S. from 1972 to 2000. For. Ecol. Manag. 222, 191-201.

Macdonald, C.A., Anderson, I.C., Bardgett, R.D., Singh, B.K., 2011. Role of nitrogen in carbon mitigation in forest ecosystems. Curr. Opin. Environ. Sustain. 3 (5), 303-310.

Mehta, N.C., Leg, J.O., Goring, C.A.I., Black, C.A., 1954. Determination of organic phosphorus in soil. I. Extraction method. Proc. Soil Sci. Soc. Am. 18, 443-449.

Paul, E.A., Clark, F.E., 1996. Soil Microbiology and Biochemistry, 2nd ed. Academic Press, San Diego, CA, pp. 368.

Paustin, K., Andren, O., Clarholm, M., Hansson, A.C., Johansson, G., Lagerlof, J., et al., 1990. Carbon and nitrogen budgets of four agro-ecosystems with annual and perennial crops with and without fertilization. J. Appl. Ecol. 27, 60-84.

Peng, C., Liu, J., Apps, M., Dang, Q., Kurz, W., 2000. Quantifying Ontario's forest carbon budget: 1. Carbon stocks and fluxes of forest ecosystems in 1990. Forest Research Report, vol. 158. Ontario Ministry of Natural Resources, Canada.

Piper, C.S., 1994. Soil, Plant Analysis. Inter Science, Adelaide.

Post, W.M., Kwon, K.C., 2000. Soil carbon sequestration and land-use change: processes and potential. Glob. Change Biol. 6, 317-328.

Rhoades, J.D., 2001, http://www.netl.doe.gov/publications/proceedings/01/carbon_ seq_terr/graves.pdf.

Rice, C.W., 2002, http://www.geotimes.org/jan02/featurecarbon.html.

Schlesinger, W.H., 1990. Evidence from chronosequence studies for a low carbonstorage potential of soils. Nature $348,232-234$

Shrestha, R.K., Lal, R., 2006. Ecosystem carbon budgeting and soil carbon sequestration in reclaimed mine soil. Environ. Int. 32, 781-796.

Singh, T.N., 2011. Assessment of coal mine waste dump behaviour using numerical modeling. In: Fuenkajorn \& Phien-wej (Ed.), Rock Mechanics. , ISBN: 978 9745336360.

Singh, V.K., 2010. Geotechnical study of coal rib and associated dump failure at a coal mine. In: ISRM International Symposium - 6th Asian Rock Mechanics Symposium, New Delhi, India, October 23-27.

Snedecor, G.W., Cochran, W.G., 1989. Stastical Methods, 8th ed. Iowa State University Press, Ames, IA, pp. 503. 
Soegaard, H., Jensen, N.O., Boegh, E., Hasager, C.B., Schelde, K., Thomsen, A., 2003. Carbon dioxide exchange over agricultural landscape using eddy correlation and footprint modelling. Agric. For. Meteorol. 114, 153-173.

Sourkova, M., Frouz, J., Santruckova, H., 2005. Accumulation of carbon, nitrogen and phosphorus during soil formation on alder spoil heaps after brown-coal mining, near Sokolov (Czech Republic). Geoderma 12, 203-214.

SPSS, 1997. https://conference.ifas.ufl.edu/citrus10/./1610\%20Spreen.pdf.

Srivastava, S.C., Singh, J.S., 1988. Carbon and phosphorus in the soil biomass of some tropical soils of India. Soil Biol. Biochem. 20, 743-747.

Srivastava, S.C., Singh, J.S., 1991. Microbial C, N and P in dry tropical forest soil: effects of alternate land uses and nutrient flux. Soil Biol. Biochem. 23 (2), 117-124.

Suyker, A.E., Verma, S.B., 2001. Year-round observations of the net ecosystem exchange of carbon dioxide in a native tallgrass prairie. Glob. Change Biol. 7, 279-289.

Suzina, N.E., Mulyukin, A.L., Kozlova, A.N., Shorokhova, A.P., Dmitriev, V.V., Barinova, E.S., Mokhova, O.N., El'-Registan, G.I., Duda, V.I., 2004. Ultrastructure of resting cells of some non-spore-forming bacteria. Microbiology 73, 435-447.

Tripathi, N., Singh, R.S., 2008. Ecological restoration of mined-out areas of dry tropical environment, India. Environ. Monit. Assess. 146, 325-337.

Tripathi, N., Singh, R.S., 2009. Influence of different land uses on soil nitrogen transformations after conversion from an Indian dry tropical forest. Catena 77 216-223.
Tripathi, N., Singh, R.S., Nathanail, C.P., 2014. Mine spoil acts as a sink of carbon dioxide in Indian dry tropical environment. Sci. Total Environ. 468-469, 1162-1171. Tunstall, B., 2010. Measuring Soil Carbon. www.eric.com.au.

Tate, K.R., Scott, N.A., Parshotam, A., Brown, L., Wilde, R.H., Giltrap, D.J., et al., 2000. A multi-scale analysis of a terrestrial carbon budget-is New Zealand a source or sink of carbon? Agric. Ecosyst. Environ. 82, 229-246 [Sp. Iss. SI].

Wali, M.K., 1999. Ecological succession and the rehabilitation of disturbed terrestrial ecosystems. Plant Soil 213, 195-220.

Yazaki, Y., Mariko, S., Koizumi, H., 2004. Carbon dynamics and budget in a Miscanthus sinensis grassland in Japan. Ecol. Res. 19, 511-520.

\section{Further reading}

Lal, R., Kimble, J.M., Follett, R.F., Cole, C.V., 1998. The Potential of US Cropland to Sequester Carbon and Mitigate the Greenhouse Effect. Ann Arbor Press, Chelsea, MI.

Lal, R., Kimble, J., Follet, R., 1998. Land use and soil C pools in terrestrial ecosystems. In: Lal, R., Kimble, J., Follet, R., Stewart, B.A. (Eds.), Management of Carbon Sequestration in Soil. Lewis Publishers, Boca Raton, FL, pp. 1-10. 